\title{
Quantitative analysis of plant biodiversity of Mount Sidi Youcef Region of Saida (Western Algeria)
}

\author{
F. Chalane ${ }^{1 *}$, A. Bekkouche ${ }^{2}$, F. Z. Yahiaoui' ${ }^{3}$, M. Hamdaoui ${ }^{5}$, Z. Mehdadi ${ }^{4}$ \\ ${ }^{1}$ University Doctor Moulay Tahar Saida, Algeria. \\ 2University Center Salhi Ahmed, Naâma, Algeria. \\ ${ }^{3}$ University Abou Bakr Belkaid, Tlemcen, Algeria. \\ ${ }^{4,5}$ University Djillali Liabes, Sidi Bel Abbes 22000, Algeria. \\ E-mail: doctchalane@yahoo.com
}

Received: 05.10.2019. Accepted: 30.10.2019

\begin{abstract}
Our work, is interested in assessing the biodiversity in the Mount of Sidi youcef region of Saida (Western Algeria), for this sixteen stations are selected, within each station, a floristic inventory has been made. The results obtained show that the species richness is 69 species, distributed in 30 botanical families dominated by Caryophylacea Poaceae and Liliaceae. The biological spectrum of these species reveals the dominance of therophytes constituted the bulk of the flora, followed by geophytes, phanerophytes, hemicryptophytes and chamaephytes. PCA statistical processing (principal component analysis) of the floristic analysis of the stations examined reveals the formation of four groups defining a set of stations marked by the presence of certain phytoecological similarity.
\end{abstract}

\section{Key words: Phytodiversité; Mont sidi youcef; Multivariate analysis}

\section{Introduction}

The Mediterranean region is very diversified by plant species and is of great interest for any scientific research. Great floristic wealth is related to the heterogeneity of paleogeographic data, geological ecological aspects (Quezel et al., 1988), but the current situation is dramatic in various North African countries (Quezel, 2000). Algeria because of its geographical position presents a great diversity of biotope occupied by an important floristic richness. Its forest ecosystems are characterized by a remarkable floristic richness, some represent landscapes of global interest. The resinous formations (Pinus halepensis, Juniperus oxycedrus, ) constitute almost the majority of forest and pre-forest ecosystems, they are also associated with Quercus ilex et Olea europea (Benabdelli, 1996). These forest formations are overgrazed and burned in recent decades. Various works have drawn the attention of biologists and geneticists to the interest of Mediterranean forests, from the point of view of plant species richness, as much in terms of the forest species that constitute them as herbaceous species that participate in the procession of habitats that they individualize (GomezCampo, 1985), It is in this context that we are interested in the study of this forest formation(Mont Sidi youcef) which is a transition zone between a forest ecosystem and a steppe ecosystem (ecotone). Ecotones occur in two ways when two plant communities or ecosystems have the same ecological amplitude growing separately in their own region (Kamel, 2003). This area of "tension"» (Cléments, 1905) can form a sharp ecotone when plant species can't coexist together. This study presents a certain originality that allowed us to evaluate in a global way the phytodiversity that characterizes our study area.

\section{Materials and Methods \\ Study area}

Our study area is a transition between the degraded green oak forest in the northern part and the Stipa tenacissima L.-based steppe to the south. The climate is Mediterranean type to cool winter, with average annual rainfall of $280 \mathrm{~mm}$ à $390 \mathrm{~mm}$. Average monthly temperatures are between $9,4^{\circ} \mathrm{C}$ et $26,6^{\circ} \mathrm{C}$, the average minimum temperatures of the coldest month oscillate between $2.8^{\circ} \mathrm{C}$ to $3.5^{\circ} \mathrm{C}$ and average maxima of the hottest month seldom exceed $32^{\circ} \mathrm{C}(\mathrm{NOM}, 2018)$. For the floristic inventory, we used the phytosociological survey method OF Braun-Blanquet (1952) the number of stations selected is 16 during the period of optimal vegetation, from April to May. Inventoried species are distributed according to their frequency of appearance $(F)$, botanical families (Quézel \& Santa, 1962), and biological types (Raunkiaer, 1934; Ellenberg \& Mueller, 1968), morphological types (Quézel \& Santa, 1962; Ozenda, 1991; Bonnier, 1990). The inventoried species are divided into three classes with respect to their frequency of occurrence (F). (Figure 1).

\section{Statistical treatment}

The similarity in species composition between the studied stations is performed by B Sorensen similarity index of (Gaujour et al., 2009; Masharabu et al., 2010) and $J$ (Jaccard) index (De Bello et al., 2007). One of the objectives of our study was also to characterize the plant biodiversity of Mount Sidi Youcef. Statistical analyses that can meet the primary objective of this ecological study PCA (Principal component analysis).

\section{Results and Discussion}

The floristic inventory conducted on sixteen stations allowed to count 69 species (Table 1). The number of species varies from 15 species (St 11 and St 15) to 29 species (St 2) this inequality testifies to the variability of the distribution of the flora in relation to the 
various factors of the environment. The inventoried species are related to 30 botanical families (Figure 2). The family which is best represented is the Caryophlaceae with a rate of $(13,04 \%)$, followed by Poaceae $(10,14 \%)$, Liliaceae with a rate of $(5,55 \%)$, then the Asteraceae Fabaceae (7,24\%) and the Convolvulaceae, Lamiaceae (4,34\%). We also noted the existence, on the one hand, of seven families (Brassicaceae, Cupressaceae, Malvaceae, Papaveraceae, Plantaginaceae, Primulaceae and the Orchidaceae) 2,89\%. The remaining fifteen families are monospecific with a low presence of (1.44\%) each, this numerical superiority is also confirmed by Guillerm (1982) within the flora of the western Mediterranean regions of Europe.

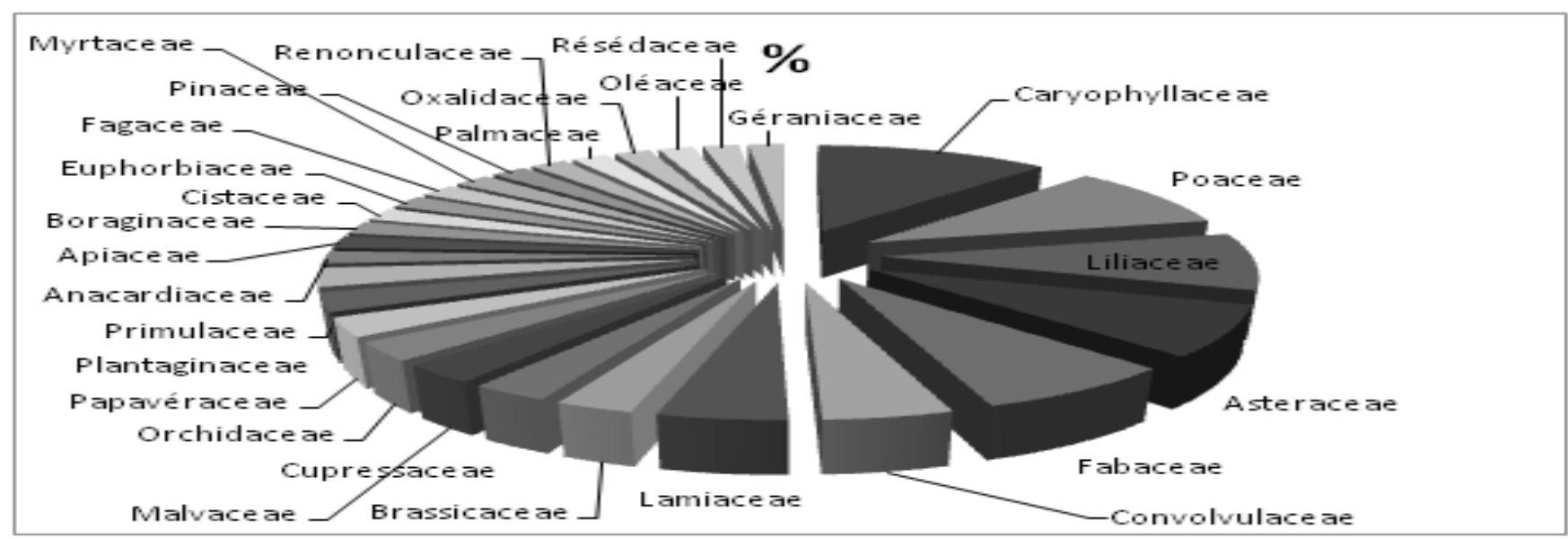

Figure 1. Distribution of botanical families in the study area.

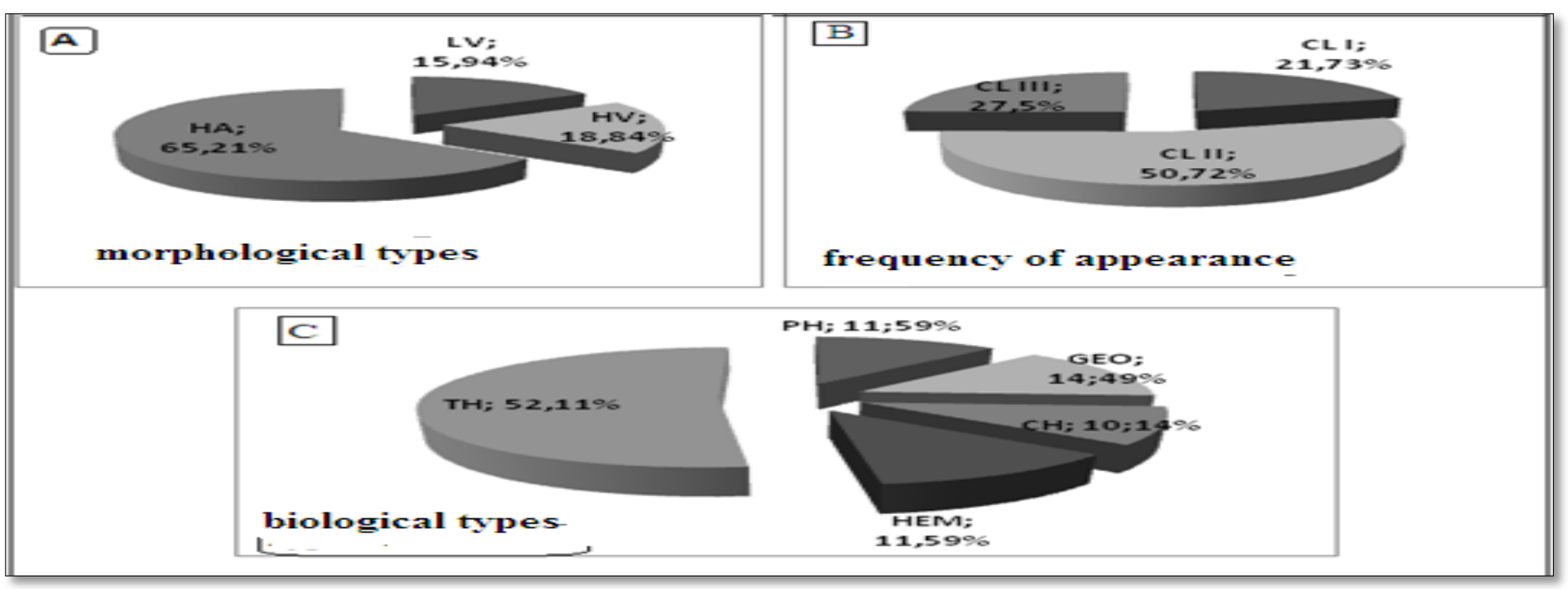

Figure 2. The classification of inventoried species according to their morphological types (A), frequency of apppearance (B) and biological types (C) in the study area.

HE: hemicryptophytes; $\mathrm{CH}$ : chamephytes; TH: therophytes; PH: phanerophytes; GE: geophytes; LV: Ligneous plants; HV: perennial herbaceous plants; HA: annual herbaceous plants CLI: class I; CLII: class II; CLIII: class III;

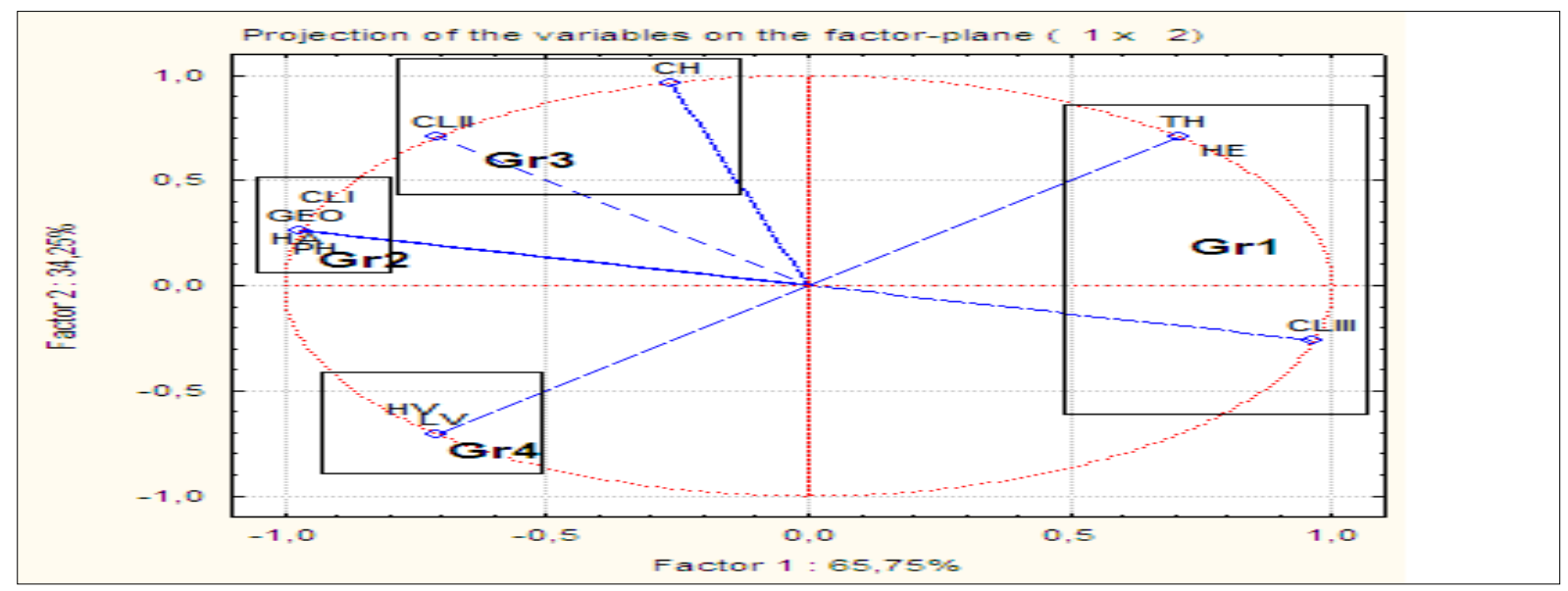

Figure 3. Principal Component Analysis (PCA).

HE: hemicryptophytes; CH: chaméphytes; TH: therophytes; PH: phanerophytes; GE: geophytes; LV: Ligneous plants; HV: perennial herbaceous plants; HA: annual herbaceous plants;

CLI: class I; CLII: class II; CLIII: class III. 
Table 1. Floristic inventory in Sidi youcef mount (the study area).

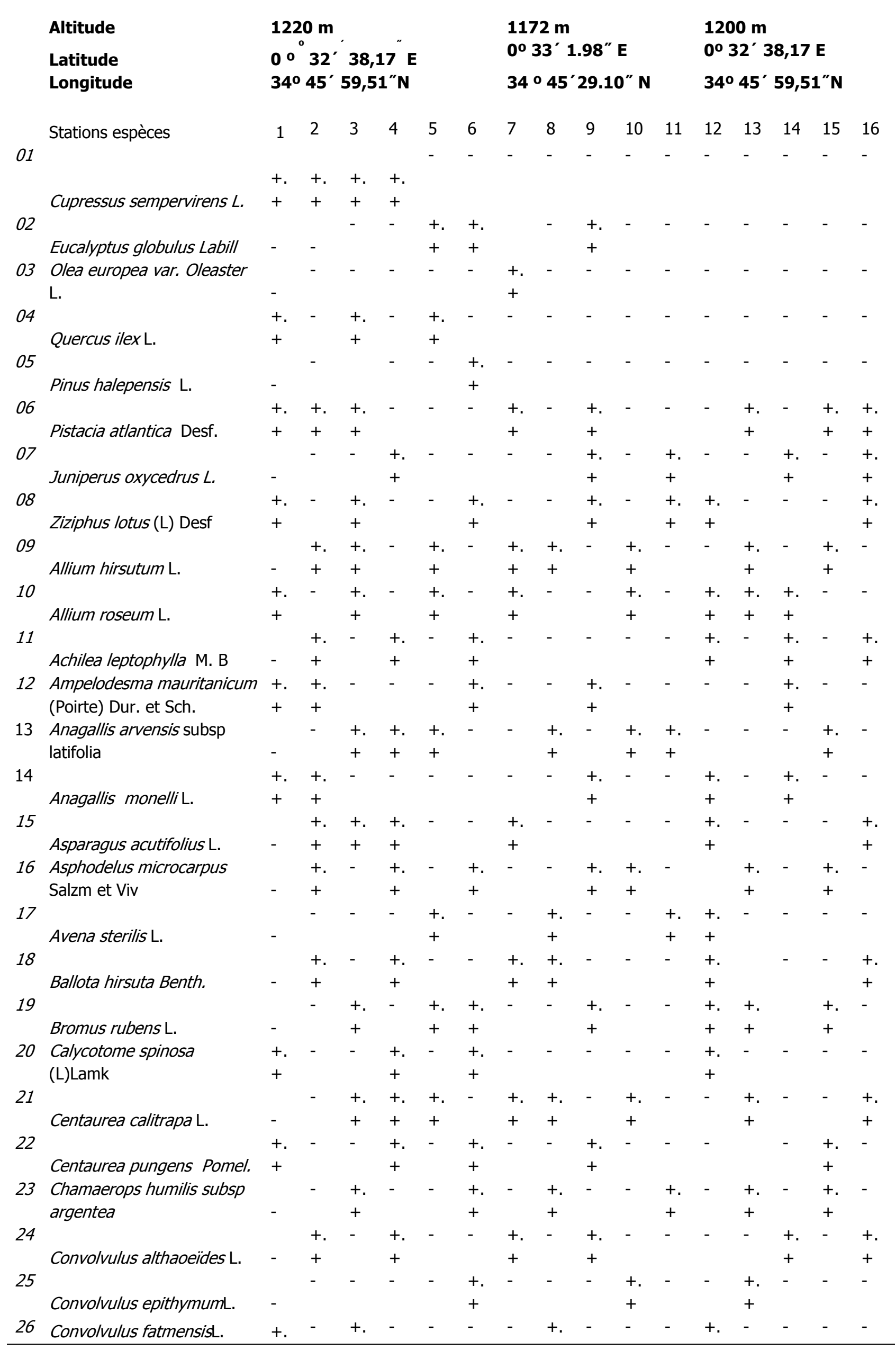




\begin{tabular}{|c|c|c|c|c|c|c|c|c|c|c|c|c|c|c|c|c|c|}
\hline 56 & Scilla peruviana $L$. & - & $\begin{array}{l}+ \\
+\end{array}$ & - & - & - & $\begin{array}{l}+. \\
+\end{array}$ & - & - & $\begin{array}{l}+ \\
+\end{array}$ & - & - & - & - & - & - & - \\
\hline 57 & Shismus barbatus P.B. & - & - & - & - & - & - & - & - & - & - & - & - & $\begin{array}{l}+ \\
+\end{array}$ & - & $\begin{array}{l}+. \\
+\end{array}$ & - \\
\hline 58 & Silene argillosa Munby. & $\begin{array}{l}+. \\
+\end{array}$ & $\begin{array}{l}+ \\
+\end{array}$ & $\begin{array}{l}+ \\
+\end{array}$ & - & $\begin{array}{l}+. \\
+\end{array}$ & - & - & - & $\begin{array}{l}+ \\
+\end{array}$ & $\begin{array}{l}+. \\
+\end{array}$ & - & $\begin{array}{l}+. \\
+\end{array}$ & - & - & - & - \\
\hline 59 & Silene aristidis Pomel. & - & $\begin{array}{l}+ \\
+\end{array}$ & - & $\begin{array}{l}+ \\
+\end{array}$ & - & $\begin{array}{l}+. \\
+\end{array}$ & - & $\begin{array}{l}+ \\
+\end{array}$ & - & - & - & & $\begin{array}{l}+ \\
+\end{array}$ & - & $\begin{array}{l}+. \\
+\end{array}$ & - \\
\hline 60 & Silene oropediorum Coss. & - & - & - & $\begin{array}{l}+ \\
+\end{array}$ & - & - & - & - & $\begin{array}{l}+ \\
+\end{array}$ & - & - & $\begin{array}{l}+. \\
+\end{array}$ & - & - & - & - \\
\hline 61 & Silene aristidis villosa Fask & - & - & $\begin{array}{l}+ \\
+\end{array}$ & - & - & - & $\begin{array}{l}+ \\
+\end{array}$ & - & - & $\begin{array}{l}+. \\
+\end{array}$ & - & $\begin{array}{l}+. \\
+\end{array}$ & $\begin{array}{l}+ \\
+\end{array}$ & - & $\begin{array}{l}+. \\
+\end{array}$ & $\begin{array}{l}+ \\
+\end{array}$ \\
\hline 62 & Sinapis arvensis $L$. & - & - & - & $\begin{array}{l}+. \\
+\end{array}$ & - & - & - & - & - & - & $\begin{array}{l}+ \\
+\end{array}$ & - & - & - & $\begin{array}{l}+ \\
+\end{array}$ & - \\
\hline 63 & Stipa tenacissima L. & $\begin{array}{l}+ \\
+\end{array}$ & - & - & - & - & - & - & - & - & $\begin{array}{l}+. \\
+\end{array}$ & - & $\begin{array}{l}+. \\
+\end{array}$ & $\begin{array}{l}+ \\
+\end{array}$ & $\begin{array}{l}+ \\
+\end{array}$ & $\begin{array}{l}+. \\
+\end{array}$ & $\begin{array}{l}+ \\
+\end{array}$ \\
\hline 64 & Thapsia garganica L. & - & $\begin{array}{l}+ \\
+\end{array}$ & - & - & - & $\begin{array}{l}+. \\
+\end{array}$ & - & - & $\begin{array}{l}+ \\
+\end{array}$ & & - & - & - & $\begin{array}{l}+ \\
+\end{array}$ & - & - \\
\hline 65 & Trifolium angustifolium L. & $\begin{array}{l}+ \\
+\end{array}$ & & $\begin{array}{l}+ \\
+\end{array}$ & - & - & - & - & $\begin{array}{l}+ \\
+\end{array}$ & & $\begin{array}{l}+ \\
+\end{array}$ & - & $\begin{array}{l}+ \\
+\end{array}$ & - & - & $\begin{array}{l}+. \\
+\end{array}$ & - \\
\hline 66 & Trifolium rugosa & - & $\begin{array}{l}+ \\
+\end{array}$ & - & - & $\begin{array}{l}+. \\
+\end{array}$ & $\begin{array}{l}+. \\
+\end{array}$ & - & & $\begin{array}{l}+. \\
+\end{array}$ & & - & - & - & - & - & $\begin{array}{l}+. \\
+\end{array}$ \\
\hline 67 & Urginea maritima & $\begin{array}{l}+ \\
+\end{array}$ & - & - & - & $\begin{array}{l}+. \\
+\end{array}$ & - & - & $\begin{array}{l}+ \\
+\end{array}$ & $\begin{array}{l}+ \\
+\end{array}$ & $\begin{array}{l}+. \\
+\end{array}$ & - & $\begin{array}{l}+. \\
+\end{array}$ & - & - & $\begin{array}{l}+. \\
+\end{array}$ & $\begin{array}{l}+. \\
+\end{array}$ \\
\hline 68 & Vicia villosa Rhoth & - & $\begin{array}{l}+ \\
+\end{array}$ & - & $\begin{array}{l}+. \\
+\end{array}$ & - & - & $\begin{array}{l}+. \\
+\end{array}$ & - & $\begin{array}{l}+ \\
+\end{array}$ & - & - & - & $\begin{array}{l}+ \\
+\end{array}$ & - & - & - \\
\hline 69 & $\begin{array}{l}\text { Xeranthemum inapertum } \\
\text { (L)Mill. }\end{array}$ & $\begin{array}{l}+. \\
+\end{array}$ & - & $\begin{array}{l}+ \\
+\end{array}$ & & - & $\begin{array}{l}+. \\
+\end{array}$ & - & $\begin{array}{l}+. \\
+\end{array}$ & - & - & $\begin{array}{l}+. \\
+\end{array}$ & - & $\begin{array}{l}+. \\
+\end{array}$ & - & - & $\begin{array}{l}+. \\
+\end{array}$ \\
\hline & Species richness & 24 & 29 & 22 & 26 & 21 & 28 & 19 & 21 & 26 & 20 & 15 & 27 & 25 & 15 & 25 & 20 \\
\hline
\end{tabular}

Table 2. Similarity indexes (Sorensen and Jaccard) of the study area.

\begin{tabular}{|c|c|c|c|c|c|c|c|c|c|c|c|c|c|c|c|c|c|}
\hline ST & 1 & 2 & 3 & 4 & 5 & 6 & 7 & 8 & 9 & 10 & 11 & 12 & 13 & 14 & 15 & 16 & \\
\hline 1 & ND & 0.22 & 0.48 & 0.2 & 0.31 & 0.23 & 0.32 & 0.35 & 0.32 & 0.31 & 0.2 & 0.31 & 0.32 & 0.3 & 0.4 & 0.36 & \multirow{16}{*}{ 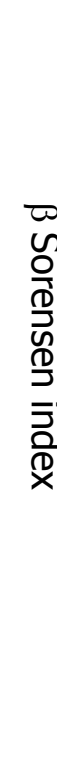 } \\
\hline 2 & 0.29 & ND & 0.27 & 0.21 & 0.2 & 0.21 & 0.2 & 0.44 & 0.5 & 0.2 & 0.22 & 0.42 & 0.37 & 0.5 & 0.37 & 0.44 & \\
\hline 3 & 0.31 & 0.15 & ND & 0.29 & 0.41 & 0.2 & 0.43 & 0.41 & 0.2 & 0.33 & 0.32 & 0.24 & 0.42 & 0.16 & 0.34 & 0.33 & \\
\hline 4 & 0.31 & 12 & 0.16 & ND & 0.08 & 0.4 & 0.26 & 0.34 & 0.19 & 0.21 & 0.34 & 0.41 & 0.22 & 0.24 & 0.19 & 0.43 & \\
\hline 5 & 0.11 & 0.11 & 0.26 & 0.04 & ND & 0.12 & 0.5 & 0.33 & 0.34 & 0.48 & 0.38 & 0.33 & 0.26 & 0.16 & 0.39 & 0.19 & \\
\hline 6 & 0.19 & 0.11 & 0.11 & 0.25 & 0.06 & ND & 0.04 & 0.28 & 0.4 & 0.25 & 0.23 & 0.36 & 0.26 & 0.27 & 0.33 & 0.25 & \\
\hline 7 & 0.13 & 0.28 & 0.28 & 0.15 & 0.33 & 0.02 & ND & 0.25 & 0.22 & 0.41 & 0.29 & 0.26 & 0.43 & 0.22 & 0.39 & 0.39 & \\
\hline 8 & 0.21 & 0.34 & 0.26 & 0.2 & 0.2 & 0.16 & 0.14 & ND & 0.04 & 0.48 & 0.33 & 0.29 & 0.43 & 0.22 & 0.39 & 0.39 & \\
\hline 9 & 0.19 & 0.11 & 0.14 & 0.1 & 0.2 & 0.25 & 0.25 & 0.02 & ND & 0.14 & 0.37 & 0.36 & 0.29 & 0.27 & 0.34 & 0.42 & \\
\hline 10 & 0.18 & 0.12 & 0.22 & 0.15 & 0.32 & 0.14 & 0.25 & 0.32 & 0.07 & ND & 0.17 & 0.38 & 0.53 & 0.22 & 0.33 & 0.53 & \\
\hline 11 & 0.11 & 0.27 & 0.19 & 0.2 & 0.24 & 0.13 & 0.17 & 0.2 & 0.23 & 0.09 & ND & 0.18 & 0.25 & 0.26 & 0.35 & 0.28 & \\
\hline 12 & 0.18 & 0.22 & 0.25 & 0.26 & 0.2 & 0.22 & 0.17 & 0.17 & 0.22 & 0.23 & 0.1 & ND & 0.15 & 0.33 & 0.38 & 0.42 & \\
\hline 13 & 0.19 & 0.22 & 0.27 & 0.13 & 0.15 & 0.15 & 0.27 & 0.27 & 0.12 & 0.36 & 0.14 & 0.08 & ND & 0.25 & 0.48 & 0.35 & \\
\hline 14 & 0.2 & 0.33 & 0.08 & 0.13 & 0.09 & 0.16 & 0.13 & 0.12 & 0.15 & 0.12 & 0.15 & 0.11 & 0.14 & ND & 0.1 & 0.22 & \\
\hline 15 & 0.25 & 0.22 & 0.28 & 0.18 & 0.24 & 0.2 & 0.18 & 0.23 & 0.2 & 0.32 & 0.21 & 0.16 & 0.31 & 0.05 & ND & 0.26 & \\
\hline 16 & 0.22 & 0.28 & 0.2 & 0.27 & 0.11 & 0.14 & 0.21 & 0.24 & 0.27 & 0.14 & 0.16 & 0.27 & 0.21 & 0.12 & 0.16 & ND & \\
\hline
\end{tabular}

The therophytes are clearly dominating all stations with (52,11\%), followed by Geophytes (GE) (14,49\%). The phanerophytes and the hemichryptophytes (11,59\%). The chamaephytes are less represented These observations are on the whole similar to that of (Dahmani et al., 1997) in the main green oak forest formations of Algerian western Tell. The high proportion of therophytes (52.11\%) is due to the microclimatic conditions: relatively wet winter and spring periods alternating with a fairly prolonged period of drought (Bekkouche el al., 2019). The more a system is influenced by man (anthropic action), the more the therophytes take up space (Floret et al., 1990, Le Floc'h, E, 2001). In addition to anthropization, therophytization is due to aridity (Barbero et al., 1990). According to Raunkiaer (1934) the increase in the rate of hemicryptophytes is related to the increase in both cold and precipitation, which corresponds to the climatic changes observed during the elevation of altitude (Kazi Tani et al., 2010). They are less likely to be drought and light chamaephytes because they are less xerophilic (Anderson 1988, Benabadji et al., Bouazza 2001). The chamaephytes are much less important. This biological type is described as being best adapted to aridity and proportionally 
established as forest ecosystems are degraded. (Ghezlaoui et al., 2011). As for the geophytes, their very small proportion is in relation with the climatic rigors favoring the development of species with short cycle of life (Aidoud, 1997). The annual herbaceous plants define the highest $(65,21 \%)$, rate, followed by perennial herbaceous plants with $(18,84 \%)$. Ligneous plants are the least represented with $(15,94 \%)$. The predominance of annual herbaceous plants is due to the invasion of therophytes, which are usually annual herbaceous plants. According to Romane (1987) "There is a good correlation between biological types and many phenomenological characters. The frequency of occurrence of inventoried species in floristic surveys revealed three classes of species: Class I with very rare species (15 species); Class II encompassing rare species (35 species); class III corresponding to frequent species (19 species); (Figure 2). shown the existence of very constant species such as Pistacia atlantica, Allium hirsutum L., Allium roseum L., Centaurea calitrapa L., Minuartia mutabilis, Ophrys speculum L., Urginea maritima et Vicia villosa which are present almost in most stations. Others are rare and very rare, representing the majority of inventoried taxa. According to (Dethier et al., 2000), the rarity of a species may be due to several reasons: it is characteristic of another environment and is therefore by accid it is "naturally" rare, its frequency is very low in all ecological conditions. In our case, it is the heterogeneity of the physical environment, its complexity combined with the different ecological stresses which are the causes of the floristic rarities encountered locally and also it is a zone of it is a zone of transition (ecotone) between forest ecosystem has a steppic ecosystem. The similarity indices of Sorensen and Jaccard (Table 2) revealed groups of stations with floristic similarities. Strong floristic similarities characterize the following groups of stations: St $10-\mathrm{St} 13(B=0,53$ et $J=0,36)$, St2-St $9(B=0,50$ et J=0, 33), St 2-St 14 ( $B=0,50$ et $J=0,33)$, St 5 -St $7(B=0,50$ et $J=0,33)$ et St 7-St $13(B=0,50$ et $J=0,27)$; however, slight similarities are noted on: St 4-St 5 $(B=0,08$ et $J=0,04)$ et St 6 -St $7(B=0,04$ et $J=0,02)$, St 8 -St $9(B=0,04$ et $J=0,02)$ St 14 -St15 $(B=0,10$ et $J=0,05)$. On the factorial plane F1 $\times$ F2 (Figure 3), the segregations secreted by the ACP concerning the different floristic results of the sixteen sampled stations are represented. The F1 axis gives more information of $65.75 \%$ against $34.25 \%$ given by the axis F2. Taking into account the contributions made by the sampled stations and the correlations between the floristic variables (Figure 3), four sets are individualized on both sides of the F1 axis: the group 1 (G1) is formed on the positive side is correlated with Therophytes (TH), hemicryptophytes (HE) and to the species of class III. On the negative side of the axis F1 is constituted by three groups G2, G3 and GR4 are correlated with ligneous plants, phanerophytes, Class I species (CLI) We recorded correlation coefficients of GR2 (0.991) between phanerophytes $(\mathrm{PH})$ and Class I species CLI, (0.999) between geophytes (GEO) represented by a maximum number with a rate of $(14.81 \%)$ and annual herbaceous HA and $(0.410)$ and the GR3 group which is correlated with perennial herbaceous plants (HV) which is presented with 13 species with (18.84\%), and Ligneous plants (LV) with (0.717) correlation for group 4 correlated with Class I species (CLI) at (0.780) correlation and chamephytes $(\mathrm{CH})$ which mark their maximum percentages of (14.49\%) and with a correlation of (0.312) On the negative side, the set of groups, correlated with species in Class II (CLII). This category of species is abundant in the study area with 35 species at a rate of $(50.72 \%)$. The floristic study by means of the sigmatist method made it possible to count 69 species forming the floristic procession participating in the important floristic richness of the Sidi youcef (Saida) mountains.

\section{Conclusion}

Following this work it appeared that the frequent heterogeneity of the vegetation in mountainous environment, the annual and even seasonal variations of the floristic richness and the state of the plant pose many Problems of final interpretation. This shows very clearly that the study sites (Mount Sidi youcef) generally constitute an important reservoir for the amount of flora with the stock of medicinal plant species and aromatic characters, the profitability offered by medicinal plants of This mountainous ecosystem, and certain that it is an economic priority that should be exploited, provided that all accompanying measures, conservation and recycling are respected to ensure the protection of plant heritage.

\section{References}

Aidoud, A. (1997). Fonctionnement des ecosystemes mediterraneens. Toulouse.

Anderson, D.M. (1988). Seasonal stooking of tabosa managed under continous and rotation grazing. - Journal of Range Management 1: 78-82.

Barbero, M., Loisel, R., Medail, F., Quezel, P. (2001). Signification biogeographique et biodiversite des forets du bassin mediterraneen. Bocconea 13: 11-25.

Bekkouche, A., Chalane, F., Guenaia, A.,Yahiaoui, F. Z., Chemouri, F. Z, Bouazza, M. (2019). phyto diversity of steppe western, algeria plant archives. 19(1): 852-856.

Benabadji, N., Bouazza, N. (2001). L'impact de I'homme sur la forêt dans la région de Tlemcen. -Forêts méditerranéennes 22: 269274.

Benabdelli, K. (1996). Aspects physionomico-structuraux et dynamique des écosystèmes forestiers face à la pression anthropozoogène dans les monts de Tlemcen et les monts de Dhaya (Algérie occidentale).- Thèse de doctorat, Université Djillali Liabés, Sidi Bel Abbés, Algérie, p. 356.

Bonnier, G. (1990). La grande flore en couleur. -Édition Belin, tomes 1-2-3-4, Paris, France. 1: 401.

Braun-Blanquet, J. (1952). Phytosociologie appliquée. Communication de Station internationale de géobotanique méditerranéenne et alpine.- Montpellier, France, pp. 156-161.

Clements, F. E. (1905). Reseach Methods in Ecology. -Lincoln, University Publishing Company, p. 334.

Dethier, M., Fagot, J. (2000). Walravens, E. Rare Species. Wildlife Notes Gembloux. 41: 51-60.

De Bello, F., Leps, J., Sebastia, M. (2007). Grazing effects on the species-area relationship: Variation along a climatic gradient in NE Spain. -Journal of Vegetation Science. 18: 25-34.

Ellenberg, S., Mueller, P. (1968). Akey of Raunkiaer plant use forms with revised. Ber. Geobot. Inst. ETH.- Stift. Rubel. Zurich 37: 56-73.

Gaujour, E., Amiaud, B., Fiorelli, J.L., Mignolet, C., Coquil, X. (2009). Effets de la dynamique des pratiques culturales lors de la conversion à l'agriculture biologique sur la végétation des prairies permanentes Innovations Agronomiques. 4: $229-238$.

Gomez-Campo, C. (1985). Plant conservation in the mediterranean area.- 6 W. Junk Publischer, Dordrecht- Boston-Lancaster, p. 269.

Ghezlaoui, B.E., Benabadji, N., Benmansour, D., Merzouk, A. (2011). Analyse des peuplements végétaux halophytes dans le Chott El-Gharbi (Oranie-Algérie).- Acta Botanica Malacitana. 36: 113-124. 
Guillerm, J.L. Maille, J. (1982). Western Mediterranean countries of Europe. In: Holzner, W. \& Numata M. (eds), Biology and ecology of weeds. The Hague, pp. 227-243.

Huetz Delemps, P. (1980). La végétation de la terre. Masson et Cie, Paris, France, p. 133.

Kamel, M. (2003). Ecotone Classification according to its origin. Pak. J Biol Sci. 6 (17): 1553-1563.

Kazi Tani, C., Le Bourgeois, T., Munoz, F. (2010). Aspects floristiques de la flore des champs du domaine phytogéographique oranais (Nord-Ouest algérien) et persistance d'espèces rares et endémiques. Flora Mediterranea 20: 5-22.

Le Floc'h, E. (2001). Biodiversité et gestion pastorale en zones arides et semi-arides méditerranéennes du Nord de l'Algérie. Bocconea 13: 223-237.

Ohba, H., Amirouche, R. (2003). Observation of the Flora of Tadmait and Tidikelt, Central Sahara, Algeria. Journal of Japanese Botany 78: 104-111.

Masharabu, Noret, T., Lejoly J., Bigendako, M.J., Bogaert J. (2010). Étude comparative des paramètres floristiques du Parc national de la Ruvubu, Burundi. - Geo-Eco-Trop. 34: 29-44.

ONM, Organisation nationale de météorologie. (2010). Recueil des données climatiques de la wilaya de Saida.- Feuilles de relevés quotidiens de la période 1980-2018, Alger, Algérie.

Ozenda, P. (1991) Flore et vegetation du Sahara.-3édition. Paris

Quezel, P., Santa, S. (1962-1963). Nouvelle flore de l'Algerie et des regions desertiques meridionales, pp. 1-2.

Quézel, P., Barbero, M., Benabid, A., Loisel, R., Rivas Martinez, S. (1988). Contribution à l'étude des groupements pré-forestiers et des matorrals rifains.- Ecologia mediterranea (1-2): 76-122.

Quezel, P. (2000). Reflexions sur l'evolution de la flore et de la vegetation au Maghreb mediterraneen. Paris.

Raunkiaer, C. (1934). The life forms of plants and statistical plant. Oxford, UK.

Romane, F. (1987). Efficacité de la distribution des formes de croissances pour l'analyse de la végétation à l'échelle régionale Thèse. Doct. Es. Sc. Marseille. vocabulaire. Inst. Dével. Fores., Minist. Agr. Direction des forêts, p. 243.

\section{Citation:}

Chalane, F., Bekkouce, A., Yahiaoui, F.Z, Mehdadi, Z, Hamdaoui, M. (2019). Quantitative Analysis of Plant Biodiversity of Mount Sidi Youcef Region of Saida (Western Algeria). Ukrainian Journal of Ecology, 9(3), 315-321. 